\title{
Contribution to improve advance directives in Portugal
}

\begin{abstract}
This article explains the state of Advance Directives (concerning living wills in case of inability to express one) in Portugal. It explores the causes of the low number of registered advance directives and proposes a standard form, one of the ways to increase citizen adherence.
\end{abstract}

Keywords: advance directive, living will, health care attorney
Volume 5 Issue I - 2020

João Carlos Macedo

Adjunct Professor, Nursing School, University of Minho, Portugal

Correspondence: João Carlos Macedo, Adjunct Professor, Nursing School, University of Minho, Ed.4, Campus Gualtar, 47। 0-057 Braga - Portugal, Tel, 25360।303,

Email jmacedo@ese.uminho.pt

Received: January 15, 2020 | Published: February 12, 2020

\section{Advance diretives in Portugal}

Advance directives (AD) is a maximum expression of exercising one's autonomy and respecting informed consent. This instrument had its origins in the USA,in the mid-1970s, more specifically with a lawyer Luis Kutner, the human-right lawyer. He began with the common law and constitutional law premises that "the law provides that a patient may not be subjected to treatment without his consent (...). The challenge was what to do about patients who no longer were capable of making health care decisions. He suggested that the individual should indicate in writing ahead of time the extent to which he or she would consent to treatment. He referred to the document as a "living will," "a declaration determining the termination of life," or a "testament permitting death,"among other names".

So the AD provide an individual a means of expressing his or her wishes for medical treatment when he or she is no longer able to make those wishes known due to incapacity ${ }^{2}$ The disclosure of the AD has been making its way in the USA and only more recently started to be implemented in several European countries. ${ }^{3}$

Only at the beginning of the 21 st century was it possible for portuguese society to have access to this instrument of prospective autonomy Portugal ratified in 2001 the Convention for the protection of human rights and dignity of the human being with regard to the application of biology and medicine: convention on human rights and biomedicine (Oviedo Convention). ${ }^{4}$ Only then could the Portuguese write an AD under Article 9 which stated:. " Previously expressed wishes -The previously expressed wishes relating to a medical intervention by a patient who is not, at the time of the intervention, in a state to express his or her wishes shall be taken into account". However, this written document was not binding on health professionals.

Finally, the advance directives were legalized in Portugal, in 2012, by Law $n^{\circ} .25 / 2012$ of 16 July. ${ }^{5}$ The law states that AD can take two forms: living will (LW) and/or appointment of attorney health care (AHC). Also determines that $\mathrm{AD}$ can be revoked at any time and has five years of validity
The AD can be written in free text or use an optional Ministry of Health form. ${ }^{6}$

Citizens can declare that their advance directive is effective when they are in one or more of these situations:

i. I have been diagnosed with terminal incurable disease

ii. Unconsciousness due to irreversible neurological or psychiatric illness complicated by complications respiratory, renal or cardiac;

iii. There are no expectations of recovery in the clinical evaluation by members of the medical team. caregiver according to state of the art;

iv. Other situations.

v. Then the citizen can indicate some instructions to health professionals, like:

vi. Not undergo artificial supportive treatment of vital functions;

vii. Not to be subjected to futile treatment, useless or disproportionate in their clinical condition and in accordance with good professional practice, particularly with regard to basic life support measures and artificial feeding and hydration measures that only aim to retard the natural process of death;

viii. Receive adequate palliative care

ix. Not be subjected to treatments that are in the experimental phase;

x. Authorize or refuse participation in scientific research programs or clinical trials;

Concerning the AHC, the portuguese legislation say that anyone can appoint one or more persons, giving them representative powers to decide on health care to receive, or not to receive, when unable to express their will personally and autonomously. The law state that $\mathrm{AHC}$ decisions must be respected by healthcare professionals. In case of conflict between the provisions set forth in the LW and the will of the AHC, the LW prevails. 
Finally, in 2014 the Health Ministery created a database, a National Register of Advance Diretives ${ }^{7}$

allowing citizens to have their AD accessible at any hospital in the country.

\section{The advance directive: numbers and causes}

According to the latest data, early 2020, Portugal has registered around 29000 AD.. Women with 19301 records, men with $10046 .{ }^{8}$

Notwithstanding some national bibliography that was emerging for citizen consultation ${ }^{9-11}$ the numbers reveal the poor adherence of the portuguese to the advance directives. There are certainly multiple factors contributing to this case.

Being aware of the low numbers of $\mathrm{AD}$ in the portuguese population, here are some of the likely underlying causes:

1. we still continue to live in a death denial society.

2. There is a need to promote education for death so that this subject can be discussed since childhood. ${ }^{12,13}$ Talking about the end of life is something that is not in people's goals, much less make the decision to think about the care you want or refuse when you are in a situation where you can not communicate your wishes;

3. We still have a very paternalistic paradigm in health care. The exercise of autonomy is not yet properly developed in the practice of care;

4. The population's health literacy level is low. There are fringes of the digital illiteracy population. In this regard, people have a hard time writing their directive; ${ }^{14-17}$

5. The Health Ministry did not make a good promotion campaign, on the Internet and social networks and forgot about people who have digital illiteracy; ${ }^{18}$ On the other hand in Portugal, in the National Health Service there is a Community Care Unit in Primary Health Care that could be, with the work mostly of nurses, the ideal place to promote and advise citizens about advance directives.

6. Health professionals do not have adequate training for counseling; ${ }^{19}$

7. The form proposed by the Health Ministry is complex and unintuitive; ${ }^{6}$

8. The lack of an advance directives guide. A guide with explanations of advance directives would allow citizens to draw up the document with more information and awareness. In Spain, in the Andaluzia region, the Ministry of Health has developed a guide for $\mathrm{AD}$ that greatly facilitates citizens. ${ }^{20}$

\section{Increase advance directives: a form proposal}

As we saw to increase the advance directives many measures are needed, however, we leave below a small contribution, a form proposal, which was inspired by various models existing in European countries. However, the biggest contribution was from the Spanish model, more specifically from Andaluzia. ${ }^{20,21}$

\section{Propose form}

\section{Advance directive}

Under and for the purposes of Law No. 25/2012 of 16 July this document reflects my early manifestation of conscious, free and enlightened will with regard to caring that I wish to receive, or do not wish to receive, if for any reason unable to express my will personally and autonomously.

This document, which I subscribe to being of legal age and capable and not being prohibited or

disabled by psychic anomaly, and unilateral by me and freely revocable at any time. I know that this document is valid for a period of five years.

\section{Identification}

Name:

\begin{tabular}{lll} 
Doc. Ident & No. & \\
Validity: & Nationality: & \\
Healthn $:$ & Date of Birth: & \\
Address: & & \\
Postale Code: & Country: & Tel.: \\
E-mail: & & \\
\hline
\end{tabular}

\section{I want to appoint my health care attorney}

Name:

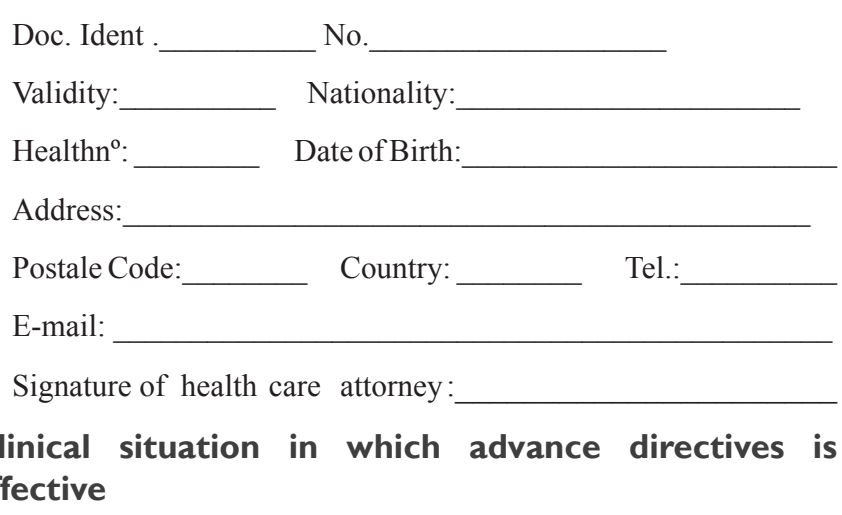

When I find myself unable to express my will autonomously as result of my state of physical and/or mental health, and if one or more of the following conditions ocurr (Figure 1):

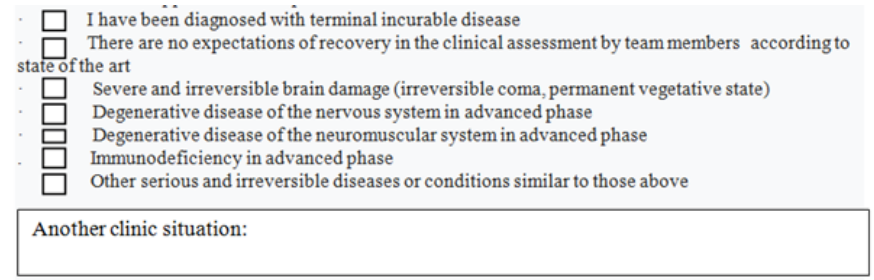

Figure I Mark with $\mathbf{X}$ the applicable assumptions below.

\section{Health care instrutions receiving/not receiving}

I direct the health care providers to withhold and withdraw treatment that merely prolongs my dying. Thus, I express my clear and unambiguous desire to (Figure 2): 
- Invasive means of artificially supporting vital functions

$\square$ I want $\square$ I refuse

- Cardiorespiratory resuscitation

$\square$ I want $\square$ I refuse

- Parenteral feeding

$\square$ I want $\square$ I refuse

- Feeding through gastrostomy

$\square$ I want $\square$ I refuse

- Feeding by naso-gastric tube

$\square$ I want $\square$ I refuse

- Intravenous hydration

$\square$ I want $\square$ I refuse

- Renal clearance techniques (hemodialysis / peritoneal dialysis)

$\square$ I want $\square$ I refuse

- Pain relief care and comfort for a serene death

$\square$ I want $\square$ I refuse

- Palliative sedation

$\square$ I want $\quad \square$ I refuse

\section{Another treatment:}

\section{Other personal considerations:}

1

\section{Signature of the declarant:}

Date:

Figure $\mathbf{2}$ Mark with $\mathbf{X}$ the applicable assumptions below.

\section{Funding}

None.

\section{Acknowledgments}

None.

\section{Conflicts of interest}

The author declare have no conflict of interest about the publication of this paper.

\section{References}

1. Sabatino CP. The evolution of health care advance planning law and policy american bar the milbank quarterly. 2010;88(2): 211-239.

2. Casey DA, Walker DM. The clinical realities of advance directives. Widener Law Review. 2011;17(2):429-442.

3. Andorno R, Biller-Andorno N, BrauerS. Advance care directives: towards a coordinated european policy. Journal of Health Law. 2009;16:207-227.

4. https://dre.pt/pesquisa/-/search/235128/details/maximized
5. ht tps://dre.pt/pesquis a//s earch/179517/details/ normal?q=Lei + n. $\%$ C2\%BA $\% 2025 / 2012+$ de $+16+$ de + julho

6. https://spms.min-saude.pt/content/uploads/2016/05/Rentev_form v0.5.pdf

7. https://dre.pt/pesquisa/-/search/25343768/details/maximized

8. https:/www.spms.min-saude.pt/2020/01/o-testamento-vital-e-um-direitodos-portugueses/

9. Santos L, Testamento vital- O que é? Como elaborá-lo. Porto: Sextante Editora; 2011

10. Nunes R, Melo HP, Testamento Vital. Coimbra: Almedina; 2011.

11. Nunes. LE quando eu não puder decidir? Lisboa: FFMS; 2016.

12. Macedo JC. Educar para a morte: uma abordagem a partir de elisabeth kübler-ross. Coimbra: Almedina; 2011.

13. Macedo JC. An approach to death education. MOJ Gerontology \& Geriatrics. 2019;4(6):276--278.

14. Espanha R, Ávila P. Health literacy survey Portugal: a contribution fot the knowledge on health and comunications. Procedia Computer Science. 2016;100:1033-1041. 
15. Paiva D, Silva S, Severo M. et al. Limited health literacy in portugal assessed with the newest vital sign. Acta Médica Portuguesa. 2017;30(12):861-869.

16. Tunzi M. Advance care directives: realities and challenge in central California. Journal Clinic Ethics. 2011;22(3):239-248.

17. Macias EA, Armaza JA, Beriain IM. Aspectos bioético-jurídicos de las instrucciones previas o testamento vital en el contexto normativo español. Acta Bioethica. 2015;21(2):163-172.

18. https://www.spms.min-saude.pt/2020/01/o-testamento-vital-e-um-direitodos-portugueses/
19. Ólafsdóttir KL, Jónsdóttir H, Fridriksdóttir N, et al.Integration-nursefacilitated advance care planning for patients newly diagnosed with advanced lung cancer. International Journal of Palliative Nursing. 2018;24(4):170-177.

20. https://www.juntadeandalucia.es/organismos/saludyfamilias/areas/ calidad-investigacion-conocimiento/calidad-sistema-sanitario/paginas/ webrva.html

21. Besirevic V. End-of-life in the 21st century: advance directives in universal rights discourse. Bioethics. 2010;24(3):105--112. 